\title{
Pendampingan Pembuatan Sistem Biopori Dalam Menanggulangi Masalah Limbah Rumah Tangga Desa Tebaban
}

\author{
Mijahamuddin Alwi*1, Musabihatul Kudsiah², Arif Rahman Hakim³, Saprudin \\ Jauhari $^{4}$, B. Fitri Rahmawati ${ }^{5}$ \\ mijahamuddin.alwi@gmail.com ${ }^{* 1}$ \\ ${ }^{1234}$ Program Studi PGSD, ${ }^{5}$ Program Studi Sejarah, Universitas Hamzanwadi
}

Received: 31 October 2021 Accepted: 06 December 2021 Online Published: 30 December 2021 DOI: 10.29408/ab.v2i2.4221

\begin{abstract}
Abstrak: Pembuatan lubang biopori tidaklah sulit dibuat dan tidak diperlukan keahlian khusus namun hasil dan manfaatnya jauh lebih besar. Biopori berfungsi sebagai resapan air, dan pengolah sampah rumah tangga. Pembuatan lubang biopori sangat mudah, metode ini cukup efektif dilakukan di lingkungan yang padat penduduk dan lahan terbatas. Tujuan dari pengabdian ini adalah memberikan pengetahuan dan aplikasinya tentang cara pengolahan sampah rumah tangga (RT) organik melalui sistem biopori, sehingga masyarakat memahami pentingnya menjaga lingkungan dan mampu menghasilkan pupuk organik untuk tanaman. Permasalahan dihadapi di desa Tebaban Barat adalah pemilahan, pemisahan, penanganan, dan pengelolaan sampah RT. Penanganan sampah RT hanya dilakukan dengan mengangkut sampah dari rumah ke rumah, kemudian di buang ke TPA. Sehingga sampah RT yang ada hanya dibungkus plastik dan menunggu jadwal pengambil sampah pada setiap minggunya, sehingga menimbulkan bau busuk. Metode pelaksanaan kegiatan pengabdian ini meliputi survei lapangan, komunikasi, kerja sama, sosialisasi, dan pendampingan. Hasil survei yang diperoleh dikomunikasikan dengan pihak desa dan warga. Kemudian dihasilkan kesepakatan berkaitan dengan pembuatan lubang biopori. Selanjutnya dilakukan sosialisasi tentang sampah dan melakukan kegiatan pendampingan pembuatan lubang biopori. Hasil dari kegiatan pendampingan warga dalam pembuatan lubang biopori 90\% warga yang hadir bisa mempraktikkan langsung pembuatan lubang biopori baik secara manual maupun dengan menggunakan bor, serta cara mengisi lubang dan memanen hasil biopori. Hasil kunjungan yang dilakukan oleh Tim PKM setelah pendampingan, 70\% warga sudah menerapkan di rumahnya masing-masing walaupun pembuatannya masih secara manual. Proses kegiatan ini mengundang ketertarikan dari sebagian masyarakat karena dilihat dari kebermanfaatan kegiatan ini sangat cocok diterapkan di lingkungan tersebut.
\end{abstract}

Kata kunci: Biopori; Limbah Rumah Tangga; Sistem Biopori

\begin{abstract}
Making Biopore holes is not difficult and does not require special skills but the results and benefits are much greater. Biopore functions as a water catchment and processing household waste. This method is quite effective in a densely populated environment and limited land. The purpose of this service is to provide knowledge and its application on how to process organic household waste through the Biopore system. The problems faced in Tebaban Barat village are sorting, separating, handling, and managing household waste. Handling household waste is only carried out by transporting waste from the house to the house, then throwing it into the landfills. So that the existing household waste is only wrapped in plastic and waiting for the schedule to pick up the landfills every week, this situation causes a bad smell. Implementing this activity includes field surveys, communication, collaboration, socialization, and mentoring. The survey results obtained are communicated with the village and residents. Then an agreement was made regarding the manufacture of Biopore holes. Furthermore, socialization about waste and conducting assistance activities for making Biopore holes was carried out. The results of the community assistance activities in making Biopore holes, $90 \%$ of the residents who attended were able to practice directly making Biopore holes either manually or using a drill and how to fill holes and harvest Biopore results. After the mentoring, the results of the visit carried out by the Team, $70 \%$ of the residents have implemented it in their respective homes even though it is still made manually. The activity invites interest from some people because it is seen from the usefulness of this activity. The Biopore is very suitable to be applied in that environment.
\end{abstract}

Keywords: Biopore; Household waste; Biopore System 
Alwi, M., Kudsiah, M., Hakim, A. R., Jauhari, S., Rahmawati, B. F. (2021). Pendampingan pembuatan Sistem Biopori dalam menanggulangi masalah limbah rumah tangga Desa Tebaban. ABSYARA: Jurnal Pengabdian Pada Masyarakat, 2(2), 291-300. doi:10.29408/ab.v2i2.4221

\section{PENDAHULUAN}

Sampah seringkali dipandang tidak memiliki manfaat dan dianggap sebagai sesuatu yang tidak bernilai dalam kehidupan manusia. Manusia menganggap sampah sebagai sisa pemanfaatan dari kegiatan yang digunakan untuk kebutuhan manusia, dan keberadaan sampah mengganggu estetika lingkungan (Kahfi, 2017).

Undang-Undang No. 18 Tahun 2008 memberikan penjelasan bahwa sampah adalah sisa kegiatan sehari-hari manusia dan/atau proses alam yang berbentuk padat. Sedangkan pengelolaan sampah adalah kegiatan yang sistematis, menyeluruh, dan berkesinambungan yang meliputi pengurangan dan penanganan sampah. Berdasarkan sifat fisik dan kimianya sampah dapat digolongkan menjadi 4 yaitu: 1) sampah organik (sampah yang mudah membusuk seperti sisa sayuran, sisa daging, daun dan lain-lain); 2) sampah anorganik (sampah yang tidak mudah membusuk seperti plastik, kertas, karet, logam, sisa bahan bangunan dan lain-lain); 3) sampah yang berupa debu/abu; dan 4) sampah yang berbahaya (B3) bagi kesehatan, seperti sampah berasal dari industri dan rumah sakit yang mengandung zat-zat kimia dan agen penyakit yang berbahaya (Wirasasmita, dkk., 2021; Fatmawati, dkk., 2020).

Tebaban adalah sebuah desa yang secara administrasi pemerintahan masuk ke wilayah kecamatan Suralaga, Kabupaten Lombok Timur, Provinsi Nusa tenggara Barat. Luas Desa Tebaban adalah 150,977 ha, dengan populasi penduduk di desa Tebaban adalah berjumlah 3.500 jiwa, terdiri 4 dusun dari yaitu Tebaban Barat, Tebaban Daya, Tebaban Timur dan Tebaban Saung. Dimana khusus Tebaban Barat terdiri dari 6 RT.

Penduduk Tebaban Barat yang berjumlah sekitar 1.150.00 jiwa kepala keluarga dalam kehidupan sehari-hari akan selalu melakukan aktivitas pembuangan sampah baik organik, anorganik maupun limbah B3, dimana sampah tersebut bisa berasal dari sisa makanan, botol plastik, kaleng, pembungkus, daun-daunan maupun yang lainnya. Sampah-sampah tersebut setiap saat dapat dibuang di tempat sampah yang sudah tersedia di masing-masing rumah warga, namun kualitas dan kuantitas sampah yang dibuang tidak pernah dihitung dan tidak dipilahpilah antara sampah organik, anorganik maupun limbah B3 sehingga bercampur aduk dan ketika petugas sampah datang pada jadwal yang sudah di tentukan yaitu 2 kali dalam 1 minggu pada hari rabu dan hari Sabtu, maka sampah-sampah tersebut langsung diangkut dengan menggunakan truk tanpa ada pemilahan.

Kegiatan pembuangan sampah tidak memiliki titik akhir, sehingga diperlukan penanganan dan pengelolaan yang konkret dan sistematis. Hal ini karena dampak yang ditimbulkan oleh sampah merupakan masalah yang sangat berpengaruh terhadap lingkungan, kesehatan, dan kehidupan sosial masyarakat. Diperlukan pendekatan strategis untuk pengelolaan sampah. Berbagai upaya telah dilakukan pemerintah dalam penanganan dan pengelolaan sampah, namun belum sampai pada penanganan yang paling rendah yaitu sampah rumah tangga (Hayat \& Zayadi, 2018).

Permasalahan dihadapi di desa Tebaban Barat adalah pemilahan, pemisahan, penanganan dan pengelolaan sampah rumah tangga. Pemilahan dan pemisahan sampah pada masyarakat khususnya desa Tebaban Barat sudah dilakukan tetapi hanya $30 \%$ masyarakat yang sudah melakukan itu pun hanya terfokus pada sampah plastik (botol minuman) yang kemudian dijual oleh masyarakat. Sedangkan untuk pengolahan sampah rumah tangga belum tersentuh sama sekali karena rendahnya pengetahuan yang dimiliki masyarakat tentang pengolahan 
sampah, sehingga diperlukan penyuluhan, pendampingan kepada masyarakat agar bisa memanfaatkan sampah rumah tangga sebagai pupuk, dikarenakan 90\% mata pencaharian masyarakat desa Tebaban sebagai petani. Penanganan sampah rumah tangga di desa Tebaban Barat hanya dilakukan dengan mengangkut sampah dari rumah ke rumah dengan menggunakan mobil sampah. Kemudian di buang pada TPA. Di TPA sampah hanya dibiarkan begitu saja selama beberapa hari, selanjutnya sampah di bakar begitu saja. Sehingga aspek lingkungan di sekitar area TPA menjadi terganggu kesehatannya, yaitu pencemaran lingkungan dan mengotori kondisi sekitar. Masyarakat desa Tebaban Barat belum melakukan pemilihan dan pemilahan sampah rumah tangga. Sehingga sampah rumah tangga yang ada hanya dibungkus plastik dan menunggu jadwal pengambil sampah pada setiap minggunya. Masyarakat Tebaban Barat juga belum mengetahui pentingnya menjaga lingkungan dengan pengelolaan dan penanganan sampah rumah tangga. Sehingga paradigma sampah masih menjadi bagian yang tidak penting, dan hanya dibuang begitu saja.

Sampah organik adalah limbah yang berasal dari sisa makhluk hidup (alam) seperti hewan, manusia, tumbuhan yang mengalami pembusukan atau pelapukan. Sampah ini tergolong sampah yang ramah lingkungan karena dapat diurai oleh bakteri secara alami dan berlangsungnya cepat. Contohnya: daun, kayu, kulit telur, bangkai hewan, bangkai tumbuhan, kotoran hewan dan manusia, sisa makanan manusia, kardus, kertas dan lain-lain. Manfaat sampah organik adalah untuk meningkatkan kesuburan pada tanah, karena bahannya organik dapat diurai oleh bakteri yang kemudian menjadi nutrisi yang sangat baik untuk pertumbuhan tanaman (Widyastuty, 2019).

Sampah organik bisa dimanfaatkan melalui pengomposan (Putra, dkk., 2021). Salah satu cara mengompos yang mudah adalah dengan membuat lubang biopori. Biopori adalah lubang-lubang di dalam tanah yang terbentuk akibat berbagai aktivitas organisme di dalamnya, seperti cacing, perakaran tanaman, rayap dan fauna tanah lainnya. Lubang-lubang yang terbentuk akan terisi udara, dan akan menjadi tempat berlalunya air di dalam tanah. Lubanglubang tersebut selanjutnya diisi bahan organik, seperti sampah-sampah organik rumah tangga, potongan rumput atau vegetasi lainnya, dan sejenisnya. Bahan organik ini kelak akan dijadikan sumber energi bagi organisme di dalam tanah sehingga aktivitas mereka akan meningkat. Dengan meningkatnya aktivitas mereka maka akan semakin banyak biopori yang terbentuk.

Biopori ini selain berfungsi sebagai resapan air, juga berguna sebagai pengolah sampah rumah tangga. Pembuatan lubang biopori sangat mudah dan sederhana, metode ini cukup efektif dilakukan di lingkungan perkotaan yang padat penduduk dan terbatasnya luas lahan. Dengan metode ini masyarakat dapat mengelola sampah dengan mudah, murah dan berkah. Metode Lubang Biopori ini mudah dibuat, murah tanpa memerlukan alat canggih dan berkah karena sampah yang dimasukkan ke dalam lubang biopori dapat dipanen dan dijadikan kompos (Azuwit, 2016). di desa Tebaban sistem biopori ini belum diterapkan sama sekali oleh masyarakat, padahal desa ini termasuk desa yang sangat padat penduduknya, dimana lahan serapan air sudah semakin berkurang dan sampah yang dihasilkan oleh masyarakat semakin banyak, sehingga metode biopori ini merupakan metode yang sangat tepat untuk mengatasi permasalahan tersebut. Dengan penerapan metode ini penanganan sampah bisa teratasi dan penggunaan pupuk kimia pada pertanian bisa berkurang. 
Adapun, tujuan dari pengabdian kepada masyarakat (PKM) ini adalah, memberikan pemahaman secara konseptual cara pemilihan terhadap sampah rumah tangga organik maupun non-organik, memberikan pemahaman kepada masyarakat melalui sistem biopori untuk pengelolaan sampah yang baik dan benar, sehingga masyarakat memahami pentingnya menjaga lingkungan, serta menghasilkan pupuk organik dan pemberdayaan kepada mitra. Serta dapat dimanfaatkan oleh mitra untuk meningkatkan kesejahteraan dan kebersihan dilingkungan.

\section{METODE PELAKSANAAN}

\section{Waktu dan Lokasi}

Kegiatan Pengabdian kepada masyarakat ini dilaksanakan selama 4 bulan dari bulan Mei sampai bulan Agustus 2021 yang bertempat di desa Tebaban dusun Tebaban Barat kecamatan Suralaga Kabupaten Lombok timur.

\section{Prosedur pelaksanaan}

Berdasarkan hasil identifikasi permasalahan yang ada di desa Tebaban khususnya dusun Tebaban Barat, maka solusi umum yang ditawarkan adalah pendampingan sistem biopori dalam menanggulangi masalah sampah/limbah rumah tangga di desa Tebaban Barat. Adapun Metode pelaksanaan dalam kegiatan pengabdian ini yaitu meliputi studi lapangan dan Diskusi dimana Tim PKM melakukan studi lapangan untuk mempelajari masalah sampah organik yang menjadi permasalahan di desa Tebaban dan mempelajari pengaruh budaya setempat terhadap permasalahan masyarakat sering menumpuknya sampah pada tempat sampah di setiap rumah akibat berhentinya pengambilan sampah oleh petugas sampah kunjungan ke desa Tebaban. Melakukan diskusi dan kerja sama dengan masyarakat, aparat pemerintahan desa Tebaban (RT, Kadus, Kepala Desa) untuk mengumpulkan data tentang permasalahan sampah yang sedang di hadapi. Data yang diperoleh digunakan untuk menyusun rencana penanganan dan pengelolaan sampah, diskusi dan konsultasi mengenai pemilahan dan pemilihan sampah, menentukan spesifikasi peralatan pendukung pengolahan sampah organik.

Metode yang dilakukan adalah Pendampingan Lingkungan sehat dan Pembuatan Biopori supaya ini memberikan pemahaman dan pembelajaran kepada masyarakat tentang bagaimana menciptakan lingkungan hidup yang sehat sebagai motivasi bagi masyarakat untuk menjadikan wilayah mereka ramah lingkungan yang berkelanjutan, pendampingan berupa pelatihan pengetahuan tentang sampah organik dan anorganik, dengan mengajak masyarakat untuk melakukan pemilahan langsung dari sampah yang sudah disediakan, pendampingan berupa pembelajaran tentang pengelolaan sampah organik, dimana sampah ini tergolong sampah yang ramah lingkungan karena dapat diurai oleh bakteri secara alami dan berlangsungnya cepat. Pendampingan berupa penyuluhan untuk pembuatan biopori sebagai tempat sampah organik pada masing-masing rumah tinggal. Penyuluhan disertai dengan memberi contoh alat biopori dan paparan praktik pembuatan biopori, dan Pendampingan berupa pelatihan tentang pembuatan biopori di halaman rumah dan di tempat yang tanahnya tertutup semen, seperti di depan garasi mobil. Kawasan hijau di halaman rumah dapat dilengkapi dengan biopori. Penerapan 3R (reduce, reuse, dan recycle) di lingkungan rumah dapat dilakukan dengan biopori. 
Alwi, M., Kudsiah, M., Hakim, A. R., Jauhari, S., Rahmawati, B. F. (2021). Pendampingan pembuatan Sistem Biopori dalam menanggulangi masalah limbah rumah tangga Desa Tebaban. ABSYARA: Jurnal Pengabdian Pada Masyarakat, 2(2), 291-300. doi:10.29408/ab.v2i2.4221

\section{Pelaksanaan Kegiatan}

Survei lokasi dilakukan oleh Tim PKM bertujuan untuk melihat kondisi lokasi dan menentukan daerah tempat pendampingan pembuatan lubang biopori. Survei lokasi melibatkan partisipasi masyarakat yaitu: pemerintahan desa (perangkat desa), tokoh masyarakat, Tim dosen dan mahasiswa. Dalam tahap perencanaan juga dibahas tentang jadwal kegiatan mulai dari sosialisasi sampai pembuatan lubang biopori. Dengan melibatkan masyarakat dari awal kegiatan diharapkan kegiatan dapat berjalan lancar karena mendapat dukungan dari masyarakat dan pemerintahan desa.

Pelaksanaan kegiatan selanjutnya dengan melakukan kerja sama dengan masyarakat dan pemerintahan desa. Pemerintahan desa diharapkan memiliki tanggung jawab untuk mengajak masyarakat menjaga kelestarian lingkungan hidup di sekitar rumah masing-masing terutama masalah sampah rumah tangga. Pemerintah desa juga mempunyai kewajiban untuk memberikan pengetahuan dan keterampilan tentang teknologi biopori. Kegiatan selanjutnya pada tahap pelaksanaan ini adalah sosialisasi tentang cara pembuatan lubang biopori dan cara penggunaan lubang biopori, panen kompos, pelatihan pembuatan lubang biopori, dengan tujuan memberikan ketrampilan membuat lubang biopori sehingga masyarakat dapat secara mandiri bisa membuat lubang biopori, serta praktik membuat, memelihara dan menggunakan lubang biopori

Pendampingan kegiatan pengabdian dilakukan dengan tujuan agar masyarakat dapat membuat lubang biopori secara mandiri dan dapat mensosialisasikan teknologi ini kepada masyarakat di wilayah lain. Lubang biopori harus dirawat supaya kualitasnya tetap terjaga dan berfungsi dengan baik. Perawatan lubang biopori dapat dilakukan dengan cara sebagai berikut: (a) Mengisi lubang biopori dengan sampah organik secara bertahap setiap lima hari sekali. (b) Lubang biopori yang sudah penuh dengan sampah organik dibiarkan sampai menjadi kompos kurang lebih selama tiga bulan. (c) Setelah sampah menjadi kompos, angkat kompos dari Lubang biopori dan siap diisi kembali dengan sampah organik yang baru. Kompos dapat digunakan sebagai pupuk tanaman.

Hasil yang diharapkan dari kegiatan ini yaitu penanganan sampah akan semakin membaik, masyarakat akan memiliki pengetahuan tentang biopori sehingga di masing-masing rumah memiliki lubang biopori yang nantinya akan diisi dengan sampah organik yang berasal dari sampah rumah tangga. Pupuk kompos yang dihasilkan pada lubang biopori bisa dimanfaatkan oleh masyarakat untuk pupuk pertanian, sehingga bisa mengurangi penggunaan pupuk kimia dan menghemat biaya yang dikeluarkan petani untuk membeli pupuk.

Tindak lanjut dari kegiatan ini adalah Tim PKM bekerja sama dengan pihak desa untuk melakukan kunjungan ke rumah masyarakat untuk melihat kondisi lubang biopori yang sudah dibuat pada lahan rumah masing-masing agar dirawat supaya kualitasnya tetap terjaga dan berfungsi dengan baik, serta tetap terisi dengan sampah organik sehingga bisa menghasilkan pupuk kompos yang berkualitas. Dari pihak desa akan melakukan pembinaan di bawah pengurus karang taruna yang mengarah kepada wirausahawan sebagai upaya untuk meningkatkan perekonomian warga. 
Alwi, M., Kudsiah, M., Hakim, A. R., Jauhari, S., Rahmawati, B. F. (2021). Pendampingan pembuatan Sistem Biopori dalam menanggulangi masalah limbah rumah tangga Desa Tebaban. ABSYARA: Jurnal Pengabdian Pada Masyarakat, 2(2), 291-300. doi:10.29408/ab.v2i2.4221

\section{HASIL DAN PEMBAHASAN HASIL}

Tahap pertama, melakukan kegiatan survei oleh Tim PKM. Tahap ini ditemukan berbagai permasalahan, di antaranya pemukiman penduduk yang sudah tidak ada jarak, belum adanya kesadaran warga dalam penanganan sampah, ditemukan banyak sampah yang berserakan di lingkungan, warga belum memilah jenis sampah, saat hujan tiba air tergenang diselokan warga akibat sampah yang menumpuk, dan lainnya. Mengacu kepada permasalahan tersebut maka perlu dilakukan pendampingan untuk membangun kesadaran warga berkaitan dengan permasalahan sampah.

Tahap kedua, menjalin komunikasi dan kerja sama dengan pihak desa. Tahap ini Tim PKM dengan pihak desa (kepala desa, kepala wilayah, tokoh masyarakat, tokoh agama, dan tokoh pemuda) di Desa Tebaban Kecamatan Suralaga untuk menyampaikan hasil temuan pada tahap pertama, sekaligus menggali lebih lanjut mengenai informasi keadaan lingkungan desa. Selain itu, komunikasi ini juga dimanfaatkan untuk mendiskusikan mengenai kesiapan pihak desa, yang akan dijadikan sasaran kerja sama. Kerja sama ini dilakukan untuk menetapkan waktu, skema/jadwal kegiatan, dan ketersediaan sarana penunjang pelaksanaan kegiatan. Berdasarkan hasil komunikasi dan kerja sama diperoleh antusias warga masyarakat, seperti ingin melihat, mendengarkan, dan berpartisipasi, serta ingin mempraktikkan kegiatan yang ditawarkan oleh tim PKM yakni pendampingan pembuatan sistem biopori.

Tahap pengorganisasian dan sosialisasi kegiatan, tahap ini pihak desa dan warga masyarakat membentuk kelompok yang terbagi dalam 5 kelompok. Satu kelompok terdiri dari 10 orang. Pengelompokan ini dimaksudkan untuk memudahkan tim PKM dan pihak desa untuk melaksanakan kegiatan pembuatan sistem biopori di masing-masing dusun/wilayah, tujuannya agar warga masyarakat ke depan dapat bekerja secara mandiri dalam penanganan sampah di wilayahnya. Setelah pengorganisasian dilakukan, Tim PKM melakukan sosialisasi kegiatan pembuatan sistem biopori, mulai dari kebermanfaatan, pelestarian lingkungan, pencegahan, kesadaran masyarakat, dan kewirausahaan.

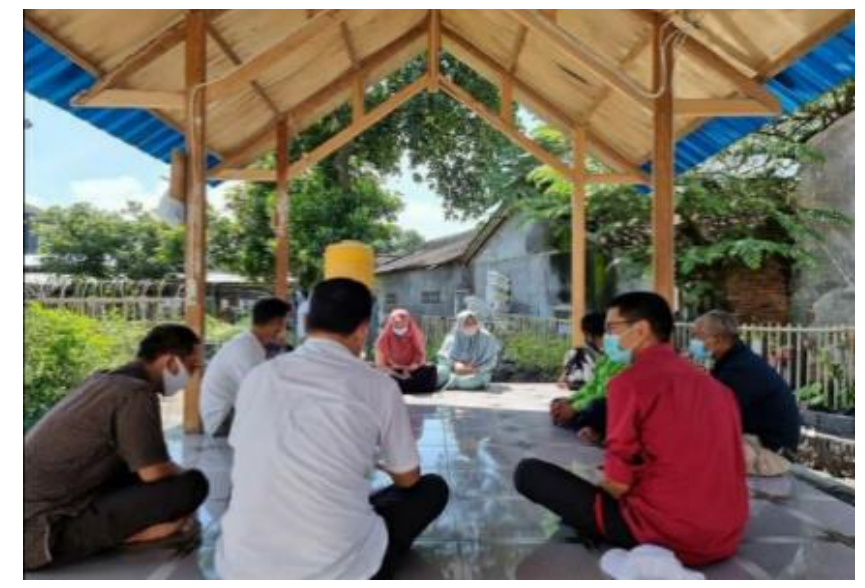

Gambar 1. Diskusi Tim PKM dengan pihak desa

Tahap pendampingan/pemberdayaan, Tim PKM memberikan memperagakan cara pembuatan lubang biopori pada setiap kelompok dengan teknik manual dan menggunakan mesin bor dengan kedalaman 1 meter. Setelah itu diperagakan cara memilah sampah organik dan anorganik untuk dimasukkan ke dalam lubang biopori sampai terisi penuh. Setelah 
memahami cara memilah dan mengisi sampah pada lubang biopori, setiap kelompok juga dibekali cara merawat dan penggunaan mikroorganisme berupa bakteri dari bahan EM4 untuk mempercepat proses penguraian sampak menjadi pupuk organik/kompos. Untuk menguatkan pemahaman masyarakat dibekali juga fase waktu panen dan cara panen dengan jarak 3 bulan dari masa pengisian dan perawatan. Kemudian Tim PKM meminta langsung kepada masingmasing kelompok untuk mendemonstrasikan langsung langkah-langkah yang sudah peragakan oleh Tim. Hasil dari kegiatan tersebut juga diaplikasikan di beberapa rumah yang ada di desa Tebaban supaya terlihat hasilnya.

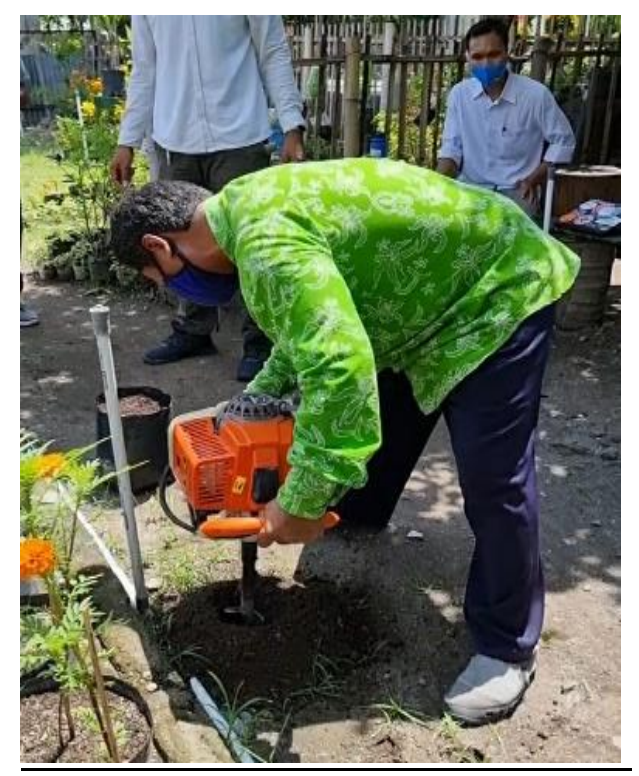

Gambar 2. Peragaan pembuatan lubang biopori dengan teknik bor oleh Tim PKM

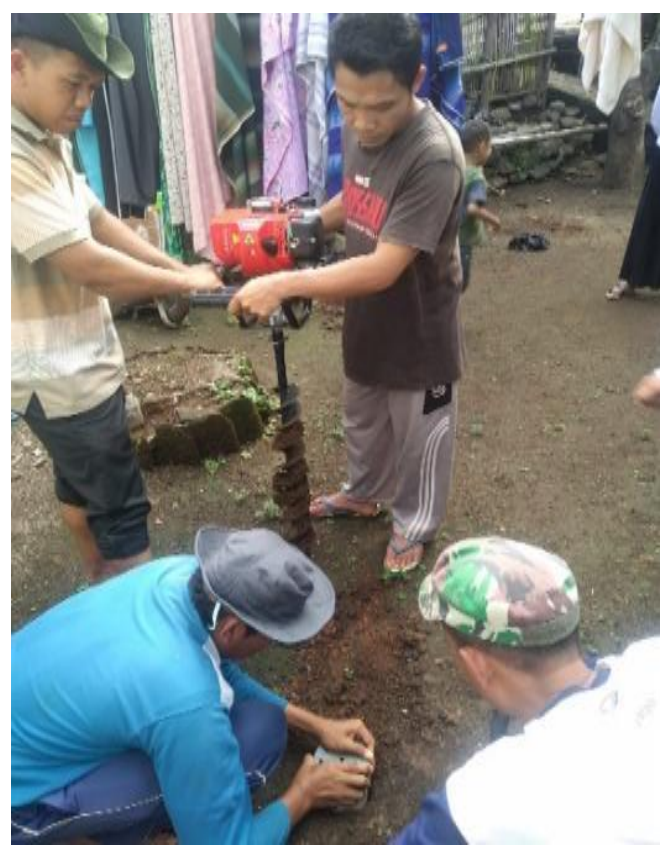

Gambar 3. Praktik pembuatan biopori oleh warga

Setelah dilakukan sosialisasi, pendampingan dan peragaan, masyarakat mulai menyadari pentingnya pemisahan dan pemilahan sampah organik dan anorganik, beberapa masyarakat 
sudah mulai menerapkan pembuatan lubang biopori di rumah masing-masing walaupun hanya dengan teknik manual. Memahami pentingnya lubang biopori dalam mengatasi sampah pada lingkungan dan sampah rumah tangga yang hasilnya bisa dimanfaatkan sebagai kompos untuk tanaman yang bisa dijual dan digunakan oleh masyarakat petani.

\section{PEMBAHASAN}

Sistem biopori ini merupakan metode yang sangat relevan untuk membantu masyarakat dalam menanggulangi limbah yang dihasilkan setiap hari. Limbah-limbah ini akan didaur ulang kembali dan dimanfaatkan sebagai pupuk organik/pupuk kompos yang bisa dimanfaatkan untuk media tanam yang baik dan menjadikan tanah menjadi lebih subur serta produktif. Metode ini sangat tepat dilakukan tidak hanya menghasilkan pupuk tetapi bisa dijadikan sebagai lubang resapan air ketika pada waktu musim hujan tiba yang nantinya bisa mengurangi debit air yang mengalir di permukaan tanah dan mencegah terjadinya banjir (Yohana, dkk., 2017). Kegiatan ini sangat cocok dilakukan pada daerah yang padat penduduk yang resapan airnya sudah berkurang karena tertutup oleh bangunan-bangunan rumah penduduk dan dibangunnya jalan-jalan yang permanen (Taufieq, dkk., 2020). Permasalahan ini sudah terjadi di desa Tebaban sehingga solusi ini sangat tepat untuk diterapkan dilingkungan tersebut.

Berdasarkan hasil survei yang dilakukan oleh Tim PKM bahwa masyarakat terkendala masalah sampah baik dilingkungan maupun limbah rumah tangga yang butuh penanganan yang serius. Dari hasil survei Tim PKM mengkomunikasikan dengan pihak desa untuk melakukan kerja sama dalam membantu masyarakat dalam penanggulangan sampah dan limbah rumah tangga. Berdasarkan hasil kesepakatan dengan pihak desa dan tokoh masyarakat maka dilakukan sosialisasi bagaimana tentang sampah, jenis sampah serta cara penanggulangan sampah dan limbah rumah tangga tersebut. Untuk mewujudkan kegiatan tersebut Tim PKM melakukan pendampingan kepada kelompok masyarakat tentang jenis sampah/limbah dan bagaimana cara memilahnya serta cara mengolahnya dengan pembuatan lubang biopori, cara perawatan, cara pengisian lubang biopori sampai pada panen kompos.

Metode pengolahan sampah ini sangat sederhana namun memberikan manfaat yang sangat luar biasa. Hasil dari pendampingan yang dilakukan $90 \%$ kelompok warga masyarakat yang hadir pada saat kegiatan bisa mempraktikkan secara langsung baik itu dengan menggunakan manual dan menggunakan bor. Saat kegiatan berlangsung Tim meminta untuk dipraktikkan langsung di beberapa rumah warga sebagai sampel dan supaya warga masyarakat bisa mengetahui langsung posisi dalam membuat lubang biopori tersebut. Antusiasme warga masyarakat Tebaban dengan kegiatan ini ditunjukkan dengan meminta pemerintah desa untuk segera merealisasikan kegiatan ini untuk semua rumah yang ada di lingkungan tersebut supaya manfaat bisa dirasakan langsung oleh warga masyarakat sekitar.

Hasil dari tinjauan setelah satu minggu kegiatan berlangsung 70\% dari kelompok warga yang didampingi sudah menerapkan hasil dari kegiatan tersebut walaupun dalam pengerjaannya masih secara manual, ini merupakan awal yang baik dari respons masyarakat. Hasil produksi yang didapatkan nanti kalau tidak digunakan oleh warga dari sistem biopori maka akan diambil oleh desa untuk dipasarkan sebagai upaya dari peningkatan perekonomian masyarakat desa, ini sesuai dengan yang dilakukan oleh Susilowati (2021) dan Reniati, dkk. (2021). Pelaksanaan kegiatan PKM ini menunjukkan bahwa pentingnya penanggulangan 
sampah/limbah di masyarakat guna memberikan kenyamanan dan keamanan serta menjaga kesehatan dari masyarakat sekitarnya, selain itu juga perlu dilakukan pengembangan kemampuan masyarakat dalam hal-hal yang positif supaya masyarakat bisa menjadi kelompok yang produktif.

\section{SIMPULAN}

Kegiatan pengabdian ini dapat di simpulkan bahwa dari survei yang dilakukan oleh tim PKM, desa Tebaban memiliki masalah dengan sampah, sehingga ketika komunikasikan ke pihak desa dan warga masyarakat maka didapatkan kesepakatan untuk dilakukan pendampingan dalam pembuatan lubang biopori sebagai upaya dalam penanggulangan sampah. Sebelum dilakukan pendampingan tim PKM melakukan kegiatan sosialisasi untuk memberikan pengetahuan tentang sampah, jenis-jenis sampah, serta bagaimana penanganan dan pengelolaan sampah. Salah satu alternatif solusi dari masalah sampah yang dihadapi masyarakat dengan membuat lubang biopori. Sehingga tim PKM bekerja sama dengan pihak desa dan warga masyarakat untuk melakukan kegiatan pendampingan dalam membuat lubang biopori. Hasil dari pendampingan yang dilakukan, antusiasme kelompok warga masyarakat cukup aktif ini terlihat $90 \%$ warga masyarakat yang hadir bisa mempraktikkan secara langsung baik secara manual maupun dengan menggunakan bor. Proses kegiatan ini mengundang ketertarikan dari sebagian masyarakat karena kalau dilihat dari kebermanfaatan kegiatan ini sangat cocok diterapkan di lingkungan tersebut mengingat di lokasi tersebut penduduknya sangat padat. Pembuatan lubang biopori tidaklah sulit dibuat dan tidak diperlukan keahlian khusus namun hasil dan manfaatnya jauh lebih besar. Biopori ini selain berfungsi sebagai resapan air, juga berguna sebagai pengolah sampah rumah tangga. Pembuatan lubang biopori sangat mudah, sederhana dan tidak memerlukan waktu yang lama, metode ini cukup efektif dilakukan di lingkungan yang padat penduduk dan terbatasnya luas lahan.

\section{PERNYATAAN PENULIS}

Artikel ini belum pernah di terbitkan pada jurnal mana pun.

\section{DAFTAR PUSTAKA}

Azuwit Gani. (2016). Lubang resapan biopori untuk penanganan sampah organik, (online). (Majalah asri.Com diakses tahun 2021).

Fatmawati, B., Adriandani, N., \& Fajri, N. (2020). Edukasi Zat Aditif Melalui Demonstrasi Kimia di MA NW Ridlol Walidain Batu Bangka. ABSYARA: Jurnal Pengabdian Pada Masyarakat, 1(1), 1-9.

Hayat, H., \& Zayadi, H. (2018). Model Inovasi Pengelolaan Sampah Rumah Tangga. JU-ke (Jurnal Ketahanan Pangan), 2(2), 131-141.

Kahfi, A. (2017). Tinjauan terhadap pengelolaan sampah. Jurisprudentie: Jurusan Ilmu Hukum Fakultas Syariah dan Hukum, 4(1), 12-25.

Putra, A. M., Hartini, H., Widiyanti, B. L., \& Haerudin, H. (2021). Sosialisasi Zero Waste dan coaching clinic pengolahan sampah di Desa Labuhan Haji. ABSYARA: Jurnal Pengabdian Pada Masyarakat, 2(1), 72-84. 
Alwi, M., Kudsiah, M., Hakim, A. R., Jauhari, S., Rahmawati, B. F. (2021). Pendampingan pembuatan Sistem Biopori dalam menanggulangi masalah limbah rumah tangga Desa Tebaban. ABSYARA: Jurnal Pengabdian Pada Masyarakat, 2(2), 291-300. doi:10.29408/ab.v2i2.4221

Reniati, R., Sumiyati, S., \& Akbar, M. F. (2021). Pelatihan pengolahan ikan dan pengemasan produk pertanian untuk pengembangan industri hilir desa Labuh Air Pandan. ABSYARA: Jurnal Pengabdian Pada Masyarakat, 2(1), 41-48.

Susilowati, E. M. (2021). Pelatihan pembuatan masker kain dalam upaya mencegah penularan Covid 19 di Surakarta. ABSYARA: Jurnal Pengabdian Pada Masyarakat, 2(1), 102-108.

Taufieq, N. A. S., Adiba, F., \& Kaswar, A. B. (2020, November). Sistem Drainase Berwawasan Lingkungan Dengan Konsep Lubang Resapan Biopori Pada Era Pandemi Covid-19. In Seminar Nasional Pengabdian Kepada Masyarakat.

Widyastuty, A. A. S. A., Adnan, A. H., \& Atrabina, N. A. (2019). Pengolahan sampah melalui komposter dan biopori di desa Sedapurklagen benjeng gresik. Jurnal Abadimas Adi Buana, 2(2), 21-32.

Wirasasmita, R. H., Arianti, B. D. D., Uska, M. Z., Kholisho, Y. N., \& Wardi, Z. (2020). Edukasi Zero Waste berbasis teknologi informasi. ABSYARA: Jurnal Pengabdian Pada Masyarakat, 1(2), 35-42.

Yohana, C., Griandini, D., \& Muzambeq, S. (2017). Penerapan Pembuatan Teknik Lubang Biopori Resapan Sebagai Upaya Pengendalian Banjir. Jurnal Pemberdayaan Masyarakat Madani (JPMM), 1(2), 296-308. 